\title{
Forced Migrants in Russia: An Analysis of Russian Law from a Human Rights Perspective
}

\author{
Samuel Marie-Fanon
}

\begin{abstract}
This paper describes the "forced return" of Russian and Russian-speaking peoples in the new "Republics" to Russia as a consequence of the collapse of the USSR. Although these migrations bear all the earmarks of a refugee displacement, they do not fall within the legitimate definitions offorced migration. Consequently,' these individuals are forced to endure all the trauma of displacement without recourse to the normative international or human rights remedies. The author suggests that two new categories, "returnees" and "returning migrants" be delineated to meet the needs of these individuals. Several examples of forced return are described in the paper to clarify the parameters of the problem and illustrate the consequences.
\end{abstract}

\section{Precis}

Ce texte decrit Ie "retour force" des personnes de nationalite ou de langue russe des nouvelles "Republiques" vers la Russie comme consequence de I' effondrement de 1'URSS. Bien que ces migrations presentent toutes les caracteristiques de la migration forcee des refugies, elles $n^{\prime}$ entren $t$ pas dans la definition traditionnelle de la migration forcee. Par consequent, ces individus sont contraints $d$ ' assumer les traumatismes de telles relocalisations sans pouvoir invoquer les remedes $d u$ droit international humanitaire. 'L' auteur suggere que deux nouvelles categories, "returnees" et "returning migrants" soient crees pour repondre aux besoins de ces individus. Plusieurs exempIes de retours fdrces sont donnes dans Ie texte afin de clarifier les parametres du probleme et en illustrer les consequences.

One of the most dramatic consequences of the collapse of the USSR is the prob-

Samuel Marie-Fanon is a student in the Refugee Studies Program at the University of Oxford, Oxford, United Kingdom. lem of refugees and forced migrants leaving the former Soviet republics to settle in Russia. The most widespread phenomenon in this forced migration appears to be the exodus of Russians as well as Russian-speaking peoples from what Russian politicians call the "near Abroad," referring to the former Soviet republics.

Despite the fact that this migratory flow seems to be a classic case of mere repatriation from the perspective of internationallaw, it however displays the very characteristics of forced migration.

Yet, there is no corresponding concept in international law, and, since they have not either left their home country or fled to Russia, forced migrants do not usually fall within the traditional concept of "refugee"l or that of "internally displaced person."2 From a juridical and legitimate perspective, this issue is but a Russian Federation concern. Like the International Community, the "traditional" international organizations in charge of helping refugees, do not have the legal right to take care of them.

Yet, even if the status of a "forced migrant" is differentfrom that of a" refugee" in terms of international law, their material deprivation and their living conditions are so similar that it might be interesting to study that legal specificity. Thus, one may ask that question: Is the Russian law regarding forced migrants adapted to the extent and seriousness of the issue? It might very well reveal the lack of political willingness of Russian authorities to get involved in the problem. Hence this creates a discriminatory situation as regards forced migrants, which does not abide the requirements of human rights.

\section{Twenty-Five Million Russians in Quest of a Lost Fatherland}

Due to the collapse of the Soviet Union, some 25 million Soviet citizens became almost overnight Russians settled in a foreign country and the living symbols of a rejected regime. $^{3}$

In a way, that sudden through passive paradoxical expatriation had been foretold for several years by growing anti-Russian feeling within the republics. In 1990, one could witness violent demonstrations against the Russians all over the country, from Kyrgyzstan, Uzbekistan and Moldova to Armenia, Azerbaijan and Tajikistan. According to the statistics, some 200,000 Russians flew from Uzbekistan during that year. ${ }^{4}$ The Soviet Far Eastwas affected as well. In the remote autonomous republic of Tuvas, near the Mongolian border, the Russian exodus from the region culminated that same year, as the acts of violence towards them were getting more serious and more frequ nt.

Obviously, the process of migration knew an even more dramatic surge after the events of 1991.

It has been often and rightfully said that the collapse of the Soviet Union caused an even greater trauma for the Russians than for the other peoples who were once part of the Union. When its fall meant for the latter the return to a long denied sovereignty, it indeed belittled the Russians from the status of "Primus inter Pares country" to that of a decaying power on the verge of sinking into the Third World. The trauma certainly proved even more profound for those "Russian of the Empire." All the former "Plan migrants" who had been sent in the republics under the framework of the Soviet Plan and who benefited there from a privileged status suddenly became refugees-or at least regarded as such, "We did become refu. gees almost overnight. We are not the ones who left our country. It is our fatherland who forsook us."s The very use of the word "refugee" to qualify those people who had not already left the republics where they used to live, the way 
this term was turned into account, showed how sound the bitterness oithe "Russians of the Empire" was. Some of them refused to adapt themselves to the new reality, but it was in no way easier for the rest to "go back" to that Russia most of them had never lived in.

Many of them were left aghast at the failed coup of 1991. In a way, their situation could be compared to that of the Algerians of European origin in the months following the signing of the 1962 EvianAgreement.

In the parent state itself (i.e., the newly born Federation of Russia), the current changes stirred questioning and thought over the role of the "Motherland" both in the press and the political circles.

The "Russians of the Empire" took advantage of the democratization of the political system and the liberalization of inforrna tion to voice their concern or their despair, and the power was, in a sense, called upon to answer for the situation. The authorities were gradually compelled to react, as their Russian brothers from the republics were now directly threatened by massive migration.

In the meantime, the fall of the USSR cleared the situation. As long as the Soviet Union existed, it was hard for the central power to deal with internal conflicts, since the "question of nationalities" had been officially settled. This proved easier when the sovereignty of the republics was proclaimed and acknowledged; the "responsibility" for the flows of refugees was to be shared between the former Soviet republics.

\section{The Legal Framework}

The law on Refugees was signed on 19 February 1993, and came into force on 20 March. The law on Forced Migrants was signed on 20 December 1995 and implemented on 28 December. ${ }^{6}$ The first one defined the provision concerning the access to the status of refugee; the second one that of the status of forced migrant. When enforced, the texts were conflated with each other and it proved difficult to determine which law should apply to any specific case.

The texts were both very similar and radically different. They were very simi- lar to one another because most of the criteria defining the status of the refugee could be found in those of the forced migrant. As a matter of fact, these criteria are those of the 1951 Geneva Convention. The Russian law pertaining to refugees was not specific.

But, as for the status of the forced migrant, the lawmakers added extra criteria in comparison with those of the refugee. Through that addition, Russia was taking care of the Russians wishing to leave the new independent states, not so much as a consequence of their being subject to persecution, but because the domestic situation in the republics would have deteriorated so seriously that it would have been impossible for the Russians to stay. This was for instance the case of the Russians living in Nagorno-Karabakh or in Abkhazia. More precisely, the texts made the distinction between two different categories based upon the concept of citizenship-a forced migrant was a Russian citizen or a former Soviet citizen living permanently on the territory of the Russian Federation and who fulfils the other provisions stated in the forced migrant laws. Moreover one must be aware of the factthatthe displaced persons within the Russian territory being also considered as forced migrants, this very category proves rather vague in comparison with traditional internationallaw.

In theory, both texts made a distinction between both categories. But in practice, the definitions appeared to be somewhat loose as a consequence of political interpretations and interference with other laws. The progress made by these two laws, i.e. the definition of two distinct statuses, was partly ruined by legal and political issues.

Even after the bills were passed, a great deal of politicians and civil servants kept on developing their own interpreting of the terms the lawmakers had decided to use. For instance, Yevgeni Chernitsov, the Government Spokesman, stated to the press that the people fleeing from Abkhazia during the war would be right away considered as refugees, whatever their citizenship.7
Even more disconcerting, if not more serious, were the statements of Tatiana Regent, the head o(the Federal Migration Service (FMS), the most important agency in charge of the implementation of those laws. She too maintained confusion over the meaning of both terms, arguing that the key distinction had to be that of people fleeing from an armed conflict zone. According to her, people leaving Tadjikistan for example had to be primarily viewed as refugees. On the other hand, the way she considered forced migrants was closer to the traditional definition of "economic migrants"-,-for instance the Armenians fleeing Armenia for Russia under economical pressure. ${ }^{8}$ Hence the prevailing confusion within the FMS and particularly on the lowest level, in the local registration offices.

But the key problem raised by these laws is that they both focus on the citizenship of the petitioner. Considering Russian law as regards citizenship, this very clause appears to be inapplicable in most cases.

As the "legal successor" of the USSR, the Federation of Russia passed a rather liberal law regarding citizenship. This text voted on 28 November 1991 and implemented on 6 February 1992 automatically granted Russian citizenship to those who used to live permanently on the soil of the Federation before that date. As for the foreigners and the Stateless persons, they had to be living in Russia for five years to have access to citizenship, that period being reduced to two and a half years for the refugees. That law defined as well a period of three years, during which any former Soviet citizen living in a former republic before 1 September 1991 could,9 upon request, have access to Russian citizenship in case she/he was not already a citizen of a postSoviet republic. After the three legal years, the former Soviet citizens had to apply for naturalization as any other foreigner.

The aim of the lawmakers was to prevent former Soviet citizens from becoming stateless persons overnight, as a consequence of the fall of the USSR. But they also wanted to spare them the risk of be corning the scapegoats of the Newly 
Independent States (NIS). This only proved true in Latvia and Estonia, but in November 1991 one could seriously fear that those NIS would pass very restrictive bills concerning citizenship.

Actually, the period of three years was extended until 31 December 2000, thanks to an amendment passed by the Duma on 18 January 1995 and confirmed by Boris Yeltsin on 6 February $1995.1^{\circ}$

By the end of February 1995, some 568,000 former Soviet citizens had obtained Russian citizenship. All of them were not registered as refugees in Russia, but those who were became forced migrants thanks to their newly acquired Russian citizenship. The criteria defined by the lawmakers in 1993 therefore proved inadequate since their implementation did not prevent the status to adapt to the situation throughout the years. For instance, in 1993, it was still not clearly stated whether the 44,400 Armenians and the 7,800 Azeris who had been registered as refugees in 1992 were still considered as such or as forced migrants. 11 As itismore interesting-in terms of material need-to be registered as a forced migrant since the government aid is more important than that granted to refugees, personal strategies and individual choice added confusion and vagueness to the current situation.

As they became aware of the imperfection of the system, the Federal Migration Service tried to clarify the situation regarding the enforcement of the law. More precisely, they issued an exhaustive list of the reasons why someone could not be entitled to participate in the mentioned categories. The economic migrants or the victims of an ecological catastrophe could be refused the status of refugee or migrant. Yet, these restrictions are far from meeting unanimous opinion within the FMS, since the director herself, Tatiana Regent, already basically considers forced migrants as economic migrants.

\section{Human Rights Versus Forced Migrants Law}

One might well question the relevance and the merits of the system of legal protection granted to "forcibly displaced persons" or forced migrants. Indeed, when it involves persons who possess the status of Russian citizens, whether they have acquired that citizenship before or after their arrival on the territory of the Russian Federation, they should not be distinguished in any way from all the other citizens. They have the same legal status and therefore should be able to enjoy all the rights and privileges conferred on them by such a status in conditions of ordinary law.

As citizens, theybenefitfrom the protection of the Russian authorities both on the territory of the Russian Federation as well as abroad in the same way as would any other citizen. Maintaining the opposite would end in evaluating the concept of citizenship as defined in international law. Consequently, by granting such citizens a special status, the law has tended to confine them to a secondary status, treating them as though they were not complete citizens. Since they are Russian citizens, it is hard to see why they should be given the benefit of a special system for identification papers, protection against refoulement, and compensation for the loss of their belongings.

On these grounds they have no need whatsoever for a derogation of ordinary law, but should be able to benefitfromit under the same conditions as any other citizens.

In the case of foreigners allowed to reside legally on the territory of the Russian Federation and who have been forced to leave their usual place of residence' the granting of the status of" forcibly displaced person" does not have any justification either. Once they have been allowed to reside legally on the territory of the Russian Federation and as long as they continue to fulfil the conditions for legal residence, there is no reason why they should be taken into account and legalized. ${ }^{12}$ They should continue to benefit from the system of ordinary law applicable to foreigners allowed to reside on the territory of the Russian Federation. The fact that they are in a special situation, namely that they have been forced to leave their usual place of residence against their will, should compel the Russian authorities to treat them as "internally displaced persons" and provide them with the same assistance as that granted to Russian citizens placed in an identical predicament.

The different categories of persons affected by the" forcibly displaced person" law have no need whatsoever of a special system of legal protection. Therefore, they should be able to benefit from the legal protection of ordinary (law. While they do not need special protection they may, on the other hand, need specific assistance, the nature of which varies according to the conditions in which they have been displaced. Those who return to their country of origin for purely economic reasons and who no longer have any ties there, should be able to receive assistance to help them to integrate. Those who were victims of discrimination, who have had their human rights denied, or were caught in the midst of armed conflicts and have had to leave without being able to prepare for their departure, often in dramatic conditions, should be able to receive a more constant and specific assistance.

It is obvious that special provisions must be adopted by States confronted with such a phenomenon so as to allow the persons concerned to become integrated in the country to which they returned. On the other hand, there should be no need to create a specific legal category.

In the case of foreign nationals allowed to reside legally on the territory of a State, and who are forced to leave their $p$ lace of usual residence because of violence, armed conflicts or serious disturbances in law and order, they quite naturally fit in the category of the "internally displaced persons," that internationallaw defines.

In the case of persons who are citizens of the country to which they return, they should be considered either as "returning migrants," if they return for purely economic reasons or for personal ones, or as" returnees," if the reasons for their leaving are linked with armed conflicts, violations of human rights or serious disturbances in law and order in 
their country of residence. These two existing categories, coming as they do under the general category of "migrants" should serve the task of establishing specific systems of assistance, yet they do not all imply any specific legal protection.

In addition to being curtailed by federal norms of lower status, the rights guaranteed by federal law and the Constitution are being eroded by regional regulations. A particularly prominent example of regional disregard for the human rights of forced migrants are the propiska regulations ("registration," to use the new terminology), i.e. residence permits required from individuals wishing to reside in a specific area in Russia. ${ }^{13}$ Although Moscow has been particularly effective in undermining the rights of forced migrants through the use of strict propiska regulations, similar measures have been taken in several other cities and regions as well. ${ }^{14}$ In addition, some regions have openly violated federal laws by adopting rigid quota for forced migrants in their jurisdiction. Yet it is obvious that federal should take precedence when local rules are in conflict with it, but in practice that principle is often disregarded. ${ }^{15}$ In some cases, it is actually the gaps in and the outdated norms of federallaw that prompted local authorities to adopt their own, often restrictive, rules on forced migrants.

\section{Conclusion: The Need to Develop and Adopt a Draft Law on Repatriation}

Migration policy, which has been aimed at holding back Russians in the former Soviet republics, can end only in disaster. In areas that have a high concentration of Russian (such as northern Kazakhstan or Ukraine), it remains critical to help Russians preserve their culture and way of life. ${ }^{16}$ However, each person who links her /his fate to Russia must have the possibility of move in a civilized manner to Russia, which declared itself the successor state to the Soviet Union. Legislation today does not allow for such a possibility. Each migrant must prove that she/he (or all Russians) is a victim of discrimination in his place of residence, which triggers a negative response from new independent States. A law guaranteeing support for voluntary migrants would fill the legislative vacuum in this area.

Thus the forced migrant law is obviously not adapted to the gravity of the issue. Moreover, it appears to be opposed to human rights for being too discriminatory. What can be the origin of the lack of political willingness within the Russian state-as shown by the enforced legal texts-when it comes to dealing with the problem of forced migrants?

Undoubtedly, Russian immigration is seen as a current economic and political burden rather than a future benefit. In addition to the costs of resettlement and higher unemployment, Russian immigrants have tended to throw their political support behind the most nationalistic politicians and parties.

Yet, this already serious issue, which is to become even graver in the coming years, might very well endanger the cohesion of the Russian State itself.

Therefore, a repatriation law would deem useful, if properly enforced, perhaps thanks to the International Community that could help the new Russian State by granting it the financial needs necessary to the enforcement of such a law .••

\section{Notes}

1. "UNHCRmandates do not apply to 'Russian Returnees'," in L. Grafova, "O krizisie sostradania napominayet vsemirnaya kostradania napominayet vsemirnaya Oslo," Literaturnaya Gazeta, Moscow, (June 15, 1994).

2. Except for the population who flew from war in Chechnya, an autonomous republic which is still part of the Russian Federation.

3. According to the 1989 Soviet census. These Russians are the largest minority in Europe today.

4. U.s. Committee for Refugees, Chapter on Soviet Union, World Refugee Survey 1991 (Washington, DC: USCR, 1991).

5. C. Messina, "Les otages de l'Empire," Refugies, no. 98 (Paris, Fall 1994): 13

6. The laws of February 1993 were the very first attempt to provide the refugees and forced migrants with a legal status. For the first time, one tried to define the party eligible for the assistance of the Federa Migration Service (FMS). The 1995 laws took over the principles of those of 1993 and are very similar. The new law supplies recognized forced migrant with a five yea status after the first registration. ( The old status after the first registion. (The old law did not specify any standard form of the migrantidentity card. As a result, the loca authorities issued different cards, which were only valid in a particular geographic area. With the new law, the forced migrant identity card is standardized and therefore valid throughout the entire territory of the Russian Federation (Article 5).

7. U.S. Committee for Refugees, Chapter on Russian Federation, World Refugee Survey 1996 (Washington, DC: USCR, 1996)

8. Ibid., 144 .

9. The Baltic countries had officially ceased of being part of the USSR since 6 September 1991.

10. "O vnesenii izmeniia v zakon Rossiskoy Federatsii 'O grajdantsve Rossiskoy Federatsii"', Rossiskaya Gazeta, (January 18, 1995)

11. U.S. Committee for Refugees, Chapter on Russian Federation, World Refugee Survey 1994 (Washington, DC: USCR, 1994).

12. N.Ayrapetova, "Migratsiyanedoljnabyt' begstvom", Nezavisimaya Gazeta (Moscow, March 1996).

13. "Bothforcedmigrantsandrefugees,however defined, are having a difficult time in the face of persistence of 'propiska' (requiring by law that residence permits from the local police secured) and the shortage of special provisions." E. Voutira, "Vestiges of Empire: Migrants, Refugees and Returnees inPostSoviet Russia," The Oxford International Review, 1996.

14. In Moscow, acquiring a forced migrants status is now inextricably linked to obtaining a temporary or permanent Propiska. Local migration services orilmt their work on the definition of forced migrant in accordance with law, but on whether the applicant will be able to get settled in the city. The lack of status leads to complete deprivation of social services.

15. See Russian Federation Constitution, art 76(5): "If there is a contradiction between federal law and another act issued in the Russian Federation, the federal law prevails."

16. "The changes perceived as a national revival by representatives of the indigenous Nation, are perceived as a social catastrophe by people belonging to the 'imperial' Nation (Le. Russians)," in J. Chinn and R. Kaiser, Russians As the New Minority: Ethnicity and Nationalism in the Soviet Successor States (Boulder, CO: Westview Press, 1996). L

Refuge, Vol. 17, No.2 (April 1998) 